\title{
REBUSAN DAUN KELOR BERPENGARUH TERHADAP TEKANAN DARAH PENDERITA HIPERTENSI
}

\author{
Destini Zebua*, Sunarti, Andriani Harahap, Fitria Ningsih, Ardedi Putra H.I.J Zalukhu, Masrini \\ Fakultas Keperawatan dan Kebidanan,Universitas Prima Indonesia, Jl. Danau Singkarak, Gg. Madrasah, \\ Sei Agul, Kec. Medan Barat, Kota Medan, Sumatera Utara 20117, Indonesia \\ *destinzebua8@gmail.com (+6282275074044)
}

\begin{abstract}
ABSTRAK
Hipertensi adalah peningkatan tekanan darah yang di tunjukan nilai sistolik dan diastolik diatas normal, upaya penanggulangan hipertensi dapat dapat dilakukan secara non-farmakologis seperti menggunakan rebusan daun kelor yang mudah ditemukan di daerah beriklim tropis seperti Indonesia tanaman ini berperan sebagai anti kolesterol, anti bakteri, anti radang, anti tumor, menurunkan kadar gula, serta menurunkan tekanan darah. Tujuan penelitian ini adalah Untuk mengetahui pengaruh rebusan daun kelor terhadap tekanan darah penderita hipertensi. Jenis penelitian menngunakan metode pre-experimental untuk melihat nilai tekanan darah sebelum dan sesudah intervensi. Lokasi penelitian dilakukan di Panti Jompo Guna Budi Bakti Medan yang direncanakan pada bulan Januari 2021. Jumlah populasi 25 orang dan jumlah sampel 25 orang dengan teknik pengambilan sampel yaitu total sampling. Hasil penelitian dengan uji Wilcoxon dengan nilai $\mathrm{p}=0,000<0,05$ artinya ada pengaruh rebusan daun kelor terhadap penurunan tekanan darah.
\end{abstract}

Kata kunci: hipertensi; rebusan daun kelor; tekanan darah

\section{MORINGA LEAF DECOCTION EFFECTS ON BLOOD PRESSURE OF HYPERTENSION PATIENTS}

\begin{abstract}
Hypertension is an increase in blood pressure that is shown above normal systolic and diastolic values, efforts to control hypertension can be done non-pharmacologically such as using a decoction of Moringa leaves which are easily found in tropical climates such as Indonesia. inflammation, anti-tumor, lowers sugar levels, and lowers blood pressure. The purpose of this study was to determine the effect of boiled Moringa leaves on the blood pressure of hypertensive patients. This type of research uses a pre-experimental method to see the value of blood pressure before and after the intervention. The location of the study was carried out at the Panti Guna Budi Bakti Medan which is planned in January 2021. The total population is 25 people and the number of samples is 25 people with a sampling technique that is total sampling. The results of the study using the Wilcoxon test with $p$ value $=0.000<0.05$, it means that there are The effect of Moringa leaf decoction on lowering blood pressure. It is hoped that this therapy can be given to patients but under the supervision of health workers.
\end{abstract}

Keywords: blood pressure; hypertension; moring a leaf decoction

\section{PENDAHULUAN}

Menurut Kemenkes RI, 2019 hipertensi merupakan peningkatan tekanan darah sistolik diatas $140 \mathrm{mmHg}$ dan tekanan diastolik diatas $90 \mathrm{mmHg}$, Penyakit ini bersifat tidak menular yang dapat membunuh penderita akibat komplikasi dari peningkatan tekanan darah seperti kerusakan pada ginjal, penyakit jantung, stroke. Menurut Yanti dan Nofia, 2018 hipertensi adalah peningkatan tekanan darah yang di 
tunjukan nilai sistolik dan diastolic diatas normal.

Berdasarkan data WHO tahun 2015 jumlah penderita hipertensi di dunia mencapai 1,13 miliar orang, wilayah Afrika memiliki prevalensi hipertensi tertinggi sebesar $27 \%$ sedangkan Asia Tenggara menepati posisi ke-3 dengan prevalensi sebesar 25\%. Berdasarkan data Riskesdas tahun 2018 prevalensi penderita hipertensi di Indonesia adalah $34,11 \%$ dari jumlah penduduk, Provinsi Kalimantan Selatan menapati posisi pertama nilai prevalensi tertinggi sebesar 44,13\% dan Provinsi Sumatera Utara menduduki urutan ke-22 dengan nilai prevalensi $29,19 \%$. Berdasarkan hasil survey di tempat penelitian di Panti Jompo Guna Bakti Medan ada 25 lansia yang menderita hipertensi.

Hipertensi memilik beberapa faktor resiko seperti umur, jenis kelamin, tingkat pendidikan, pekerjaan, tempat tinggal, dan gaya hidup, maka diperlukan upaya penanggulangan hipertensi dapat di lakukan dengan pendekatan farmakologis seperti pemberian obat hipertensi yang terdiri dari diuretic,Angiotensin Receptor Blocker, Calcium Channerl Blockers, dan anti hipertensi lainnya (Kemenkes RI, 2019), upaya penanggulangan hipertensi dapat dapat dilakukan secara non- farmakologis seperti menggunakan rebusan daun kelor yang mudah ditemukan di daerah beriklim tropis seperti Indonesia, tanaman ini berperan sebagai anti kolesterol, anti bakteri, anti radang, anti tumor, menurunkan kadar gula, serta menurunkan tekanan darah (Yanti dan Nofia,2018).

Daun kelor mengandung antioksidan antara lain alkaloids, saponin, fitosterols, tannins, fenolik,polyphenol dan flavonoid. Kadar Polyphenol dan flavonoid pada daun kelor diketahui lebih tinggi dibandingkan daun lain seperti daun labu silam dan daun pakis. Daun kelor juga memiliki kandungan vitamin C $220 \mathrm{mg} / 100 \mathrm{~g}$ daun. Kandungan vitamin $\mathrm{C}$ daun kelor ini hampir 4 kali lebih banyak daripada daun lainnya seperti daun kenikir yang memiliki kandungan vitamin $\mathrm{C}$ $64,6 \mathrm{mg} / 100 \mathrm{~g}$ daun dan daun pepaya yang memiliki kandungan vitamin $\mathrm{C}$ $61,8 \mathrm{mg} / 100 \mathrm{mg}$ daun. Semua zat yang terkandung tersebut dapat mencegah LDL- oks. (Alverina, dkk, 2017). Daun kelor memngandung potassium yang dapat mengendalikan tekanan darah dan kandungan fitosferol yang mencegah peningkatan kolesterol jahat dalam darah (Yanti dan Novia, 2018).

Berdasarkan hasil peneilitian yang dilakukan oleh Yanti dan Novia tahun 2018 menunjukan bahwa air rebusan daun kelor dapat menurunkan tekanan darah dengan nilai $\mathrm{p}=0,000$ $<0,05$ dengan rata- rata tekanan darah dari 16 orang kelompok intervensi systole 153,50 dan diastolik 94,38 maka setelah pemberian rata-rata tekanan darah sistole 129,56 dan diastolik 86,25. Hasil penelitian yang dilakukan oleh Alverina, dkk (2017) setelah pemberian $600 \mathrm{~kg} / \mathrm{bb}$ esktrak daun kelor menunjukan hasil yang signifikan mencegah nekrosis kardiomosit dengan hasil uji one-way ANOVA p-value = $0,000<\mathrm{p}=0,05$.

Berdasarkan latar belakang di atas penelti tertarik untuk meneliti pengaruh rebusan daun kelor terhadap penurunan tekanan darah karena pengobatan ini termasuk pengobatan non-farmakologis sehingga meminimalisir penggunaan obat-obatan farmakologis yang memiliki efek samping kepada lansia. 


\section{METODE}

Jenis penelitian menngunakan metode pre - experimental yaitu metode untuk melihat pengaruh rebusan daun kelor terhadap tekanan darah penderita hipertensi di Panti Jompo Guna Budi Bakti Medan dengan melihat nilai tekanan darah sebelum tindakan(pre-tes) dan sesudah tindakan (pro-test). Lokasi penelitian dilakukan di Panti Jompo Guna Budi Bakti Medan. Peneliti mengambil lokasi penelitian ini dengan alasan jumlah populasi dan sampel yang mencukupi untuk penelitian dan adanya izin dari pihak Panti Jompo Guna Budi Bakti Medan. Penelitian ini dilakukan pada bulan Januari 2021. Populasi dalam penelitian ini adalah seluruh penderita hipertensi di Panti Jompo Guna Budi Bakti Medan dengan jumlah populasi 25 orang. Teknik pengambilan sampel pada penelitian ini yaitu total sampling teknik pengambilan sampel
Analisis data dalam penelitian secara univariat dilakukan untuk mendapatkan gambaran distribusi frekuensi responden setiap variabel yang diteliti. Analisis univariat bertujuan untuk melihat gambaran setiap variabel yang akan diteliti dalam distribusi frekuensi. Analisis univariat dalam penelitian ini disajikan dalam bentuk tabel dan narasi. Analisis data bivariat bertujuan untuk mengetahui pengaruh rebusan daun kelor terhadap tekanan darah penderita hipertensi di Panti Jompo Guna Budi Bakti Medan dengan menggunakan uji Wilcoxon.

\section{HASIL}

Hasil penelitian yang dilakukan kepada responden di Panti Jompo Guna Budi Bakti Medan 2021, mengenai pengaruh rebusan daun kelor terhadap tekanan darah penderita hipertensi, maka di dapat hasil sebagai berikut:

Tabel 1.

Nilai Tekanan Darah Pasien Hipertensi Sebelum Pemberian Rebusan Daun Kelor

\begin{tabular}{lcc} 
& $(\mathrm{n}=25)$ & \\
\hline Variabel & $\mathrm{f}$ & \\
\hline Tekanan darah & & - \\
Normal & - & 44 \\
Pra-Hipertensi & 11 & 56 \\
Hipertensi & 14 & .
\end{tabular}

Tabel 2.

Nilai Tekanan Darah Pasien Hipertensi Sesudah Pemberian Rebusan Daun Kelor $(n=25)$

\begin{tabular}{lcc}
\hline \multicolumn{1}{c}{ Variabel } & $\mathrm{f}$ & $\%$ \\
\hline Tekanan darah & & \\
Normal & 6 & 24 \\
Pra-Hipertensi & 19 & 76 \\
Hipertensi & - & - \\
\hline
\end{tabular}


Tabel 3 .

Pengaruh Rebusan Daun Kelor Terhadap Tekanan Darah Penderita Hipertensi $(n=25)$

\begin{tabular}{|c|c|c|c|c|c|c|c|}
\hline \multirow{2}{*}{$\begin{array}{l}\text { Rebusan } \\
\text { daun kelor }\end{array}$} & \multicolumn{3}{|c|}{ Tekanan darah } & & \multirow{2}{*}{$\begin{array}{c}\text { Std } \\
\text { Deviasi }\end{array}$} & \multirow[t]{2}{*}{$\mathrm{Z}$} & \multirow{2}{*}{$\begin{array}{c}\mathrm{p}- \\
\text { Value }\end{array}$} \\
\hline & Normal & Pra Hipertensi & Hipertensi & Mean & & & \\
\hline Pre test & - & 11 & 14 & 2,56 & 0,50 & & \\
\hline Post test & 6 & 19 & - & 1,76 & 0,435 & - 4,472 & 0,000 \\
\hline
\end{tabular}

Tabel 1 dilihat berdasarkan variabel tekanan darah sebelum intervensi (pretest). Responden yang mayoritas hipertensi sebanyak 14 orang $(56 \%)$ dan minoritas responden dengan prahipertensi sebanyak 11 orang $(44 \%)$. Tabel 2 dilihat berdasarkan variabel tekanan darah sesudah intervensi (post test). Responden yang mayoritas tekanan darah pra-hipertensi sebanyak 19 orang $(76 \%)$ dan minoritas tekanan darah normal sebanyak 6 orang (24\%).

Tabel 3 tahap dilakukan analisis untuk melihat perubahan nilai tekanan darah sebelum dan sesudah dilakukan pemberian rebusan daun kelor. Tabel 3 dapat dilihat dari 25 responden diketahui hasil uji Wilcoxon signed rank test diperoleh nilai $\mathrm{Z}=-4,472$ dengan $p$-Value $=0,000<0,05$ sehingga keputusan Ho ditolak $\mathrm{Ha}$ diterima yang berarti ada pengaruh rebusan daun kelor terhadap tekanan darah penderita hipertensi.

\section{PEMBAHASAN}

Penelitian ini menggunakan metode pre-experimental dengan melihat nilai sebelum dan sesudah tindakan, jumlah responden dalam penelitian ini sebanyak 25 orang dengan teknik pengambilan sampel total sampling yaitu mengambil keseluruhan jumlah populasi menjadi sampel. Penelitian ini dilakukan di Panti Jompo Guna Budi Bakti Medan yang dilaksanakan pada bulan Januari 2021.Hasil analisis yang telah dilakukan akan diuraikan sebagai berikut:

\section{Nilai Tekanan Darah Sebelum Diberikan Rebusan Daun Kelor pada Penderita Hipertensi}

Berdasarkan variabel tekanan darah sebelum intervensi (pre-test). Responden yang mayoritas hipertensi sebanyak 14 orang (56\%) dan minoritas responden dengan pra-hipertensi sebanyak 11 orang (44\%). Menurut Yanti dan Novia 2018 hipertensi merupakan gangguan pada aliran sistemik yang diakibatkan meningkatnya tekanan sistolik dan diastolik jantung, gangguan ini berupa penyumbatan pada pembuluh darah sehingga aliran darah tidak dapat mengalir dengan baik ke organ tubuh dan memicu peningkatan tekanan sistol dan diastol jantung dalam jangka waktu lama akan menimbulkan komplikasi seperti penyakit ginjal,stroke dan jantung. Penurunan tekanan darah tinggi dapat diatasi secara non farmakologi seperti penggunaan air rebusan daun kelor yang mengandung asitosterol sebanyak $0,09 \%$ yang berperan sebagai anti hiperglikemia yang menurunkan kadar LDL sebagai salah satu pemicu hipertensi, daun kelor juga mengandung antioksidan flavonoids dan polyphenols yang memiliki peran yang sama sebagai anti hiperlipidemia (Alverina,dkk ,2016) .

Hasil penelitian lain yang dilakukan oleh Yanti dan Novia 2018 menunjukan rata- rata tekanan darah sistolik responden sebelum diberikan rebusan daun kelor 153,50 dan rata- rata tekanan darah diastolik 94,38. Penelitian yang dilakukan oleh Alverina,dkk (2016) 
dibagi menjadi dua kelompok yaitu tikus yang tidak diberikan ekstrak daun kelor dengan tikus yang akan diberikan daun kelor yang telah diekstrak dengan pemberian dosis $200 \mathrm{mg} / \mathrm{kgBB}, 400$ $\mathrm{mg} / \mathrm{kgBB}$ dan $600 \mathrm{mg} / \mathrm{kgBB}$ personde setelah dua jam dilakukan pemberian diet aterogenik dalam waktu 28 hari kemudian diambil organ untuk diteliti jumlah sel kardiomiosit yang nekrosis.

Menurut asumsi peneliti tekanan darah tinggi timbul akibat adanya plak pada pembuluh darah sehingga menyebabkan peningkatan tekanan pada sistol dan diastol jantung, jika dalam jangka yang lama tidak diberi penanganan akan berdampak buruk bagi organ tubuh yang lain dan penanganannya dapat dilakukan secara non- farmakologis.

\section{Nilai Tekanan Darah Sesudah Diberikan Rebusan Daun Kelor pada Penderita Hipertensi}

Hasil penelitian berdasarkan variabel tekanan darah sesudah intervensi (post test). Responden yang mayoritas prahipertensi sebanyak 19 orang $(76 \%)$ dan minoritas tekanan darah normal sebanyak 6 orang (24\%). Daun kelor merupakan tanaman liar yang tumbuh dimana saja yang mengandung pottasium dan kalium yang berperan dalam penurunan tekanan darah serta kandungan fitosferol yang berperan mengurangi kolesterol jahat dalam dalah sehingga plak dari kolesterol jahat tidak dapat menyumbat pembuluh darah yang menyebabkan tekanan darah meningkat (Yanti dan Novia,2018). Daun kelor dapat menurunkan kolesterol jahat karena memiliki efek hipolipedemik yang dapat mempengaruhi homeostatis lipid dengan penghambatan lipase dan kolesterol esterase dengan senyawa flavonoid (Barawi, dkk, 2019).
Hasil penelitian lain yang dilakukan oleh Yanti dan Novia 2018 menunjukan rata- rata tekanan darah sistol setelah diberikan rebusan daun kelor 129,56 dan tekanan diastol 86,25. Hasil penelitian yang dilakukan oleh Alverina,dkk (2016) menunjukan setelah pemberian ekstrak daun kelor kebanyakan sel-sel nekrosis pada kardiomiosit tikus akan tetap tinggi secara konstan tetapi perubahan jumlah sel nekrosis yang menurun setelah pemberian $1 \mathrm{mg}$ ekstrak daun kelor bisa menurunkan sel nekrosis sampai 0,026 satuan. Menurut asumsi peneliti penurunan tekanan darah setelah pemberian rebusan daun kelor disebabkan oleh kandungan flavonoid yang berperan sebagai anti hiperlipidemia dan kalium dan potassium sebagaik anti hipertensi.

\section{Pengaruh Rebusan Daun Kelor Terhadap Tekanan Darah pada Penderita Hipertensi}

Hasil penelitian menunjukan dari 25 responden diketahui hasil uji Wilcoxon signed rank test diperoleh nilai $\mathrm{Z}=-4,472$ dengan $p$-Value = $0,000<0,05$ sehingga keputusan Ho ditolak Ha diterima yang berarti ada pengaruh rebusan daun kelor terhadap tekanan darah penderita hipertensi. Pemberian rebusan daun kelor setiap hari $250 \mathrm{ml}$ selama 7 hari akan memberikan efek pada tekanan darah karena kandungan dari kalium dan pottasium yang mampu melemaskan pembuluh darah sehingga beban jantung untuk memompa dan mengalirkan darah keseluruh tubuh akan menurun sehingga hasil yang didapatkan tekanan darah tersebut menjadi menurun (Yanti dan Novia, 2018). Penurunan tekanan darah tinggi dapat diatasi secara non farmakologi seperti penggunaan air rebusan daun kelor yang mengandung a-sitosterol sebanyak $0,09 \%$ yang 
berperan sebagai anti hiperglikemia yang menurunkan kadar LDL sebagai salah satu pemicu hipertensi, daun kelor juga mengandung antioksidan flavonoids dan polyphenols yang memiliki peran yang sama sebagaik anti hiperlipidemia (Alverina,dkk, 2016).

Hasil penelitian lain yang dialkukan oleh Yanti dan Novia 2018 setelah pemberian rebusan daun kelor nilai $p$ value yang didapatkan yaitu $\mathrm{p}=0,000<$ 0,05 yang berarti ada pengaruh air rebusan daun kelor terhadap penurunan tekanan darah.Hasil penelitian Alverina,dkk (2016) menunjukan ekstrak daun kelor memberikan manfaat untuk mencegah nekrosis kadiomiosit pada dosis $400 \mathrm{mg} / \mathrm{KgBB}$ berpengaruh sebesar 78,5\% terhadap berapa jumlah sel kardiomiosit. Menurut asumsi peneliti setelah dilakukan uji nilai tekanan darah sebelum dan sesudah dengan uji wilcoxon maka didapatkan nilai $\mathrm{p}=0,000<0,05$ dengan keputusan Ho ditolak dan $\mathrm{Ha}$ diterima sehingga ada pengaruh rebusan daun kelor terhadap tekanan darah penderita hipertensi.

\section{SIMPULAN}

Berdasarkan hasil penelitian sebelum intervensi (pre-test). Responden yang mayoritas hipertensi sebanyak 14 orang (56\%) dan minoritas responden dengan pra-hipertensi sebanyak 11 orang $(44 \%)$. Berdasarkan hasil penelitian sesudah intervensi (post test). Responden yang mayoritas prahipertensi sebanyak 19 orang $(76 \%)$ dan minoritas tekanan darah normal sebanyak 6 orang (24\%).

Berdasarkan hasil uji Wilcoxon signed rank test diperoleh nilai $\mathrm{Z}=-4,472$ dengan $p$-Value $=0,000<0,05$ sehingga keputusan $\mathrm{Ho}$ ditolak $\mathrm{Ha}$ diterima yang berarti ada pengaruh rebusan daun kelor terhadap tekanan darah penderita hipertensi.

\section{DAFTAR PUSTAKA}

Alverina,Cindy,dkk. (2016). Pengaruh Pemberian Ekstrak Daun Kelor (Moringa Oleifera) Terhadap Sel Kardiomosit Pad Tikus Putih (Rattus Novergicus Strain Wistar) Dengan Diet Aterogenik. Vol.12 No.1

Kemkes.go.id. (2021). Kementerian Kesehatan Republik Indonesia. https://www.kemkes.go.id/article/ view/19051700002/hi pertensipenyakit-paling-banyak- diidapmasyarakat.html. diakses 14 April 2021

Kurniasih. (2016). Khasiat dan Manfaat Daun Kelor Untuk Penyembuhan Berbagai Penyakit.Pustaka Baru Press : Yogyakarta

Nugroho, Wahyu. (2020). Gambar Rebusan Daun Kelor Untuk Menurunkan Kadar Gula Darah Pada Penderita Diabetes Melitus Di Sukoharjo. Jurnal Keperawatan GSH 6(1).

Pikir, Budi, dkk. (2015). Hipertensi Manajemen Komprehensif. Airlangga University Press : Surabaya

Riskesda.(2018). Hasil Riskesdas 2018. Kemenkes Badan Penelitian dan Pengembangan Kesehatan

Satrianawaty,dkk. (2019). Pengaruh Pemberian ekstrak Daun Kelor (Moringa Oleifera) Terhadap Kadar Kolesterol HDL Tikus Putih (Rattus Norvegicus) Jantan Galur Wistar Hiperglikemia Dengan Induksi Aloksan.Hang Tuah Medical Journal 17 (1) 
Supardi. (2013). Metode Riset Keperawatan. Penerbit Buku Kesehatan : Jakarta

Susilo, Yekti, Ari Wulandari. (2018). Cara Jitu Mengatasi Hipertensi. Penerbit Andi : Yogyakarta

Yanti, E. (2019). Pengaruh Pemberian Rebusan Daun Kelor (Moringa Olifiera) Terhadap Tekanan Darah Pada Penderita Hipertensi. jik : jurnal ilmu kesehatan, 3(1)

Nurlaela, H., Suhadiyah, S., Johannes, E., \& Hasyim, Z. (2015). uji efektivitas ekstrak daun kelor moringa oleifera lamk. terhadap penurunan kadar glukosa darah pada mencit Mus musculus L. Jf Fik Uinam, 2(3), 115-120. https://doi.org/10.1152/jn.00127.2 $\underline{003}$

Perry, potter dan. (2005). Buku Ajar Fundamental Keperawatan konsep, proses dan praktek.

RI, Kementerian Kesehatan, B. (2013). Riset Kesehatan Dasar. Riset Kesehatan Dasar.

Rista E, dkk. 2012. (2012). Online di : asupan protein, lemak jenuh, natrium serat dan IMT terkait dengan tekanan darah pasien hipertensi di rsud tugerejo semarang, 1, 21-29.

Suddarth. (2012). Buku Ajar Keperawatan Medikal Bedah Konsep Proses dan praktek.

Wahyudi, I., \& nurhaedah. (2017). Ragam Manfaat Tanaman Kelor ( Moringa oleifera Lamk) Bagi Masyarakat. Balai Litbang Lingkungan Hidup Dan Kehutanan Makassar, 14(1) 
Jurnal Penelitian Perawat Profesional, Volume 3 No 2 Hal 399 - 406, Mei 2021

Global Health Science Group 